\title{
Strength and Durability of Roofing PVC Membranes in the Conditions of Climate Impacts
}

\author{
M.A. Zagorodnikova, V.P. Yartsev*, V.G. Rupyshev \\ Tambov State Technical University, 112D, Michurinskaya St., Tambov, 392032, Russia \\ * Corresponding author. Tel .: +7 47526303 80.E-mail: kzis@nnn.tstu.ru
}

\begin{abstract}
Waterproofing PVC membranes are widely applied as roofing materials. Under such operating conditions PVC membranes are open to aging under the influence of various environmental factors: air temperature and humidity, ultraviolet radiation, mechanical loads. The aim of the work is to study physical and mechanical properties taking into account the influence of typical aggressive influences and evaluation of the durability of PVC membranes used as roofing materials.

The mechanism of destruction processes of polymers and polymer composites exposed to aging under the influence of temperature and humidity of air, ultraviolet radiation, mechanical loads is considered. The values of the strength characteristics and coefficients of linear thermal extension of PVC membranes are obtained taking into account the effect of UV radiation. When using PVC membranes as a roof coating, it is necessary to take into account the possibility of thermal extension under the influence of high temperatures and plasticity increase.

The durability of PVC membranes was estimated without taking into account external atmospheric and climatic influences from the view of the thermofluctuation theory of the strength of solids. On the basis of the obtained values of physical constants the regularities are derived allowing us to predict the performance parameters of the material taking into account external influences at specified values of tension, temperature and operating time.
\end{abstract}

\section{Keywords}

Waterproofing PVC membranes; polyvinyl chloride; roofing; durability; strength; aging.

(C) M.A. Zagorodnikova, V.P. Yartsev, V.G. Rupyshev, 2019

\section{Introduction}

In recent years, waterproofing membranes based on polyvinyl chloride (PVC membranes) have been widely applied as roofing materials in the construction of large industrial buildings and pavilions of large-scale space [1]. Under such operating conditions PVC membranes are open to aging under the influence of various environmental factors: air temperature and humidity, ultraviolet radiation, mechanical loads and other impacts.

The basis for predicting of the durability of polymeric materials presents the determination of the patterns of changes in their structure over time [2]. Under the influence of aggressive factors in polymeric materials the processes occur, accompanied by a change in their chemical and physical structures, as well as degradation of physical and mechanical properties [3].
Many scientists have been concerned with the problems of polymeric composites aging and predicted their longevity.

In $[4,5]$, the magnitude of the tensile forces arising in waterproofing membranes as a result of wind pressure on the roof covering was determined. In lowinclined roofs, wind suction (negative pressure) occurs at certain wind speeds, which causes the separation of membranes in loose areas and the formation of a wavy surface. However, the authors did not take into account such an important factor as the aging of PVC under climatic influences.

In [6] the analysis of deterioration of waterproofing shells of flat roofs was made. The authors, basing on the results of modern research methods, found degradation processes, namely, the reduction in the chlorine and carbon content in plasticized PVC membranes in contact with extruded polystyrene in combination with exposure to weather 
factors. This aging of PVC membranes increases their fragility and reduces mechanical properties.

A study by Italian scientists [7] showed that roof waterproofing membranes can influence the energy consumption of a building. The authors studied the influence of aging caused by the action of solar radiation and other climatic factors in Rome and Milan on the light reflectivity of the coating. The 24-month aging led to an increase in energy consumption for air conditioning systems, on average by $25 \%$. Moreover, the membrane reflection coefficient decreased from 0.8 to 0.56 , which led to an increase in temperature on their surface by $16^{\circ} \mathrm{C}$.

The work of Czech researchers [8] covered the problems of long-term degradation in soil conditions of waterproofing polymer-based membranes, including PVC used in foundations. The authors examined the effect of soil bacteria, high temperature and air humidity, and the radon gas, contained in the soil, on the mechanical properties of membranes and found significant changes in them.

In [9] Pavlov generalized the results of domestic and foreign studies of the aging of various polymers (in particular, PVC) in natural and simulated conditions. In $[10,11]$, the processes of changing the physical and mechanical properties and structure of PVC coatings during photo-aging were described, and the correlation between micro- and macrostructural changes in the polymer was revealed. In [12] the results of numerous studies of weather resistance of PVC were presented. The changes in the properties of various polymeric and wood-polymer composites were considered in [13 - 17]. The problem of predicting the durability of composite building materials was raised in the works of both Russian [18, 19] and foreign authors [20-22].

In [23], the authors made an attempt to develop a program for the experimental study of the strength and deformation properties of PVC membranes used in combined coatings of buildings operated under difficult conditions and influenced by solar radiation, sediments, snow loads, dust and wind blankets. The authors found that in the process of using such roofing coatings the inelastic deformations take place, that can lead to a decrease in the mechanical performance of the membranes and their fastening and, therefore, to an early breach in the coating tightness. The reason for this is negligence of the temperature deformations of the polymer material during its installation, leading to the appearance of significant initial stresses in hot and cold climates. In turn, the shrinkage of PVC membranes was accompanied by the opening of butt joints and the breach of waterproofing. Unfortunately, the authors modelled the influence of only force factors of environmental and climatic nature and did not take into account the synergistic effect of solar radiation, humidity, temperature fluctuations and other aggressive environments.

The analysis of modern international publications on the effectiveness of polymer waterproofing materials [24-30] showed that the main factors affecting the performance of $\mathrm{PVC}$ are temperature, humidity and solar radiation. However, the approaches suggested by the authors for prediction of longevity did not take into account these factors. Therefore, one of the topical scientific problems in the field of research of polymer roofing materials is the prediction of their durability, considering the influence of aggressive factors.

The aim of this study is to examine physical and mechanical properties taking into account the influence of typical aggressive impacts and evaluation of the durability of PVC membranes used as roofing materials. Based on the results obtained in the previous studies and presented in [31, 32], it can be concluded that the durability of PVC membranes can be predicted from the perspective of the thermofluctuation theory of the strength of solids $[18,19]$. The application of this approach will make it possible to evaluate the performance of the material in a wide range of loads, temperatures and operating time. In this regard, this paper proposes to determine the nature of the influence of UV radiation on the physical and mechanical characteristics of PVC membranes, and also to estimate the durability of PVC membranes from the standpoint of the thermofluctuation theory of strength.

\section{Methods}

For the tests we used two types of PLASTFOIL ${ }^{\circledR}$ PVC membranes manufactured by extrusion and calendaring from suspended PVC with the addition of fillers and technological additives:

\section{PLASTFOIL ${ }^{\circledR}$ ECO $1.5 \quad(1.5 \mathrm{~mm}$ thick,} reinforced with polyester mesh)

2. PLASTFOIL ${ }^{\circledR}$ Classic $1.2 \quad(1.2 \mathrm{~mm}$ thick, reinforced with polyester mesh)

The samples of PVC membranes made in the shape of strips of $200 \times 20 \mathrm{~mm}$, numbered and signed were UV-aged for 1000 hours.

Then short-term shear tests were conducted on the samples on a lever-type installation. The values of destructive tensions were calculated using Formula (1):

$$
\sigma=\frac{P}{\pi d h},[\mathrm{MPa}]
$$


where $P$ is the load applied to the sample, $d$ is the diameter of the cutting punch; $h$ is the thickness of the sample.

The schemes for setting the lever type and the device for testing the shear are given in Figs 1 and 2.

The samples were made in the shape of strips of $52 \times 15 \mathrm{~mm}$ to determine the coefficient of linear thermal expansion. The tests were carried out on an optical dilatometer. Two samples were used for each material: exposed to UV aging for 100 hours and without external influences. Based on the test results, dilatometric curves were set with the coordinates $\Delta L-t$ (sample extension-temperature).

The coefficient of linear thermal extension was determined by Formula (2):

$$
\alpha=\frac{1}{l_{0}} \frac{l_{1}-l_{0}}{t_{1}-t_{0}},\left[1 /{ }^{\circ} \mathrm{C}\right]
$$

where $l_{0}$ and $t_{0}$ are the initial length and temperature of the sample, respectively; $l_{1}$ is the length of sample at temperature $t_{1}$.

The final value of the coefficient was determined by formula (3) as the averaged value:

$$
\alpha_{\text {mean }}=\frac{\sum \alpha_{i} \Delta T_{i}}{\sum \Delta T_{i}},\left[1 /{ }^{\circ} \mathrm{C}\right],
$$

where $\alpha_{i}$ is the value of the linear thermal coefficient on the $i$ section, $\Delta T_{i}$ is the temperature range for this section.

The durability was evaluated from the standpoint of the thermofluctuation theory of the strength of solids with a graphical-analytical method. For this relatively long-term tension the long-term shear tests of samples were conducted at a lever-type installation. Five samples were tested under the same conditions and the time of damage was determined for fixed parameters $\sigma$ and $T$. For each type of membrane, the dependences
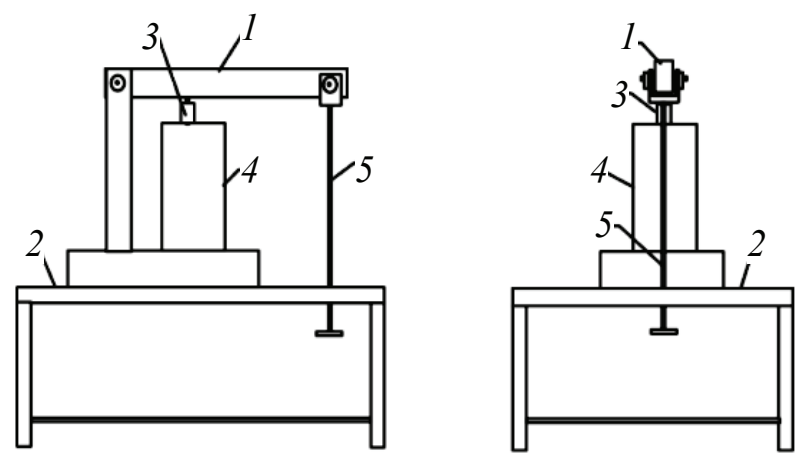

Fig. 1. Shear test bench:

1 - lever; 2 - table; 3 - shear testing device; 4 - stand; 5 - hanger
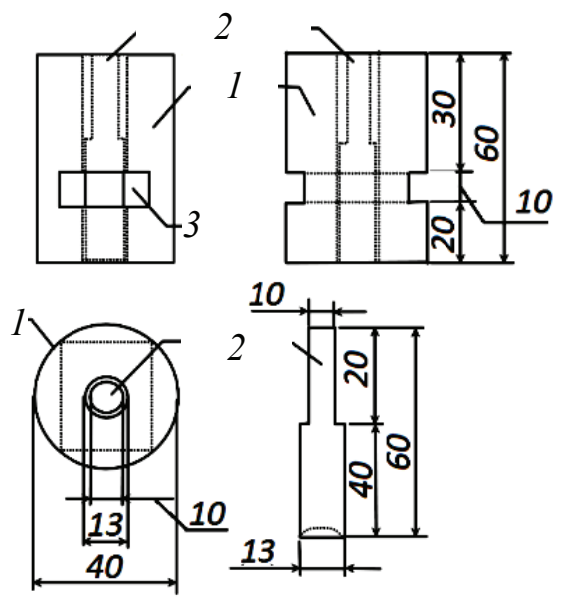

10

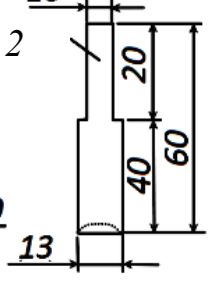

a)

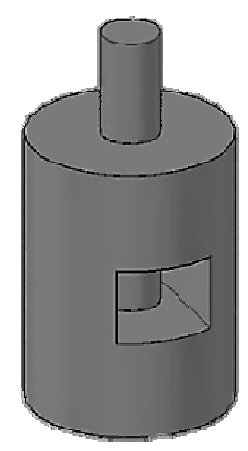

b)

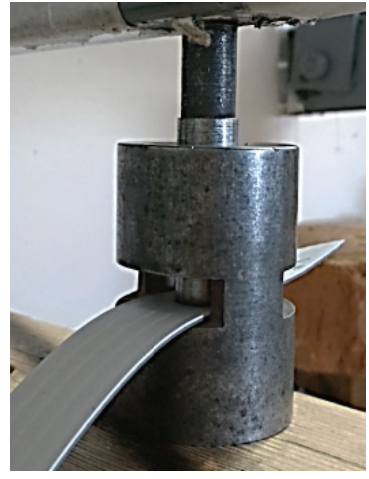

c)
Fig. 2. Device for testing polymeric materials on the shear:

$a$-scheme of the device: 1 - cylinder; 2 - hole for cutting punch with sharp edges; 3 - hole for mounting the sample; $b$ - volumetric model of adaptation; $c$ - general view of the device with sample

of the longevity on the voltage in the coordinates $\lg \tau-\sigma$ at a constant temperature were designed. The correlation of time to destruction $(\tau)$ with tension $(\sigma)$ and temperature $(T)$ is described by equation (4) for "direct beam":

$$
\tau=\tau_{m} \exp \left[\frac{U_{0}-\gamma \sigma}{R T}\left(1-\frac{T}{T_{m}}\right)\right],
$$

where $\tau_{m}$ is the minimum durability (the period of vibration of kinetic units: atoms, molecules, segments), s; $U_{0}$ is the maximum activation energy of the fracture process, $\mathrm{kJ} / \mathrm{mol} ; \gamma$ is the structural-mechanical constant, $\mathrm{kJ} /(\mathrm{mol} \cdot \mathrm{MPa}) ; T_{m}$ is the limit temperature of the solid existence (decomposition temperature), $\mathrm{K} ; R$ is the universal gas constant, $\mathrm{kJ} /(\mathrm{mol} \cdot \mathrm{K}) ; \tau$ is the time to destruction (strength durability), s; $\sigma$ is tension, MPa; $T$ is temperature, $\mathrm{K}$. 


\section{Results and discussion}

In this paper, the strength characteristics of PVC membranes were studied taking into account the effect of UV radiation. Based on the results of destructive tensions, the tension versus the duration of photo-aging was presented in Fig. 3.

Fig. 3 shows that the strength of PVC membranes increases with the rise in the duration of UV aging from 0 to 400 hours on average by $20 \%$. In this case, the graphs for all the samples are practically linear dependences. For a given period of time, the strength growth is associated with orientation phenomena in the polymer structure.

However, the kinetics of the change in strength is non-monotonic, which is also confirmed in $[10,11]$. When the duration of UV influence increased, the strength decreased, which was associated with the onset of destructive processes. In the initial period the increase in hardness was due to a decrease in the content of the plasticizer in the mixture, then dehydrochlorination, oxidation, and degradation of chains began, as a result of which the polymer structure changed. As a result of the polymer structuring the strength increased a little. At later stages of aging, the strength decreased monotonically due to accumulation of microdamages. The changes in the polymer structure can also be traced on dilatometric curves [33, 34]. Fig. 4 shows the dependencies obtained in the study of the thermal expansion of PVC membrane samples without external influences and after 100 hours of UV aging.

After UV aging (Fig. 4b) an increase in the relative extension of the samples by an average of $30 \%$ was observed with respect to the initial values, i.e., the material became more plastic when heated. One can also notice that the material structure was balanced and

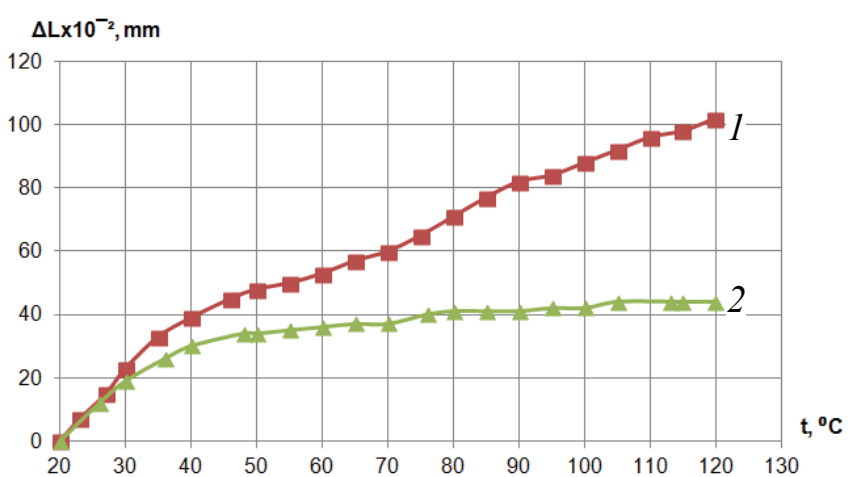

a)

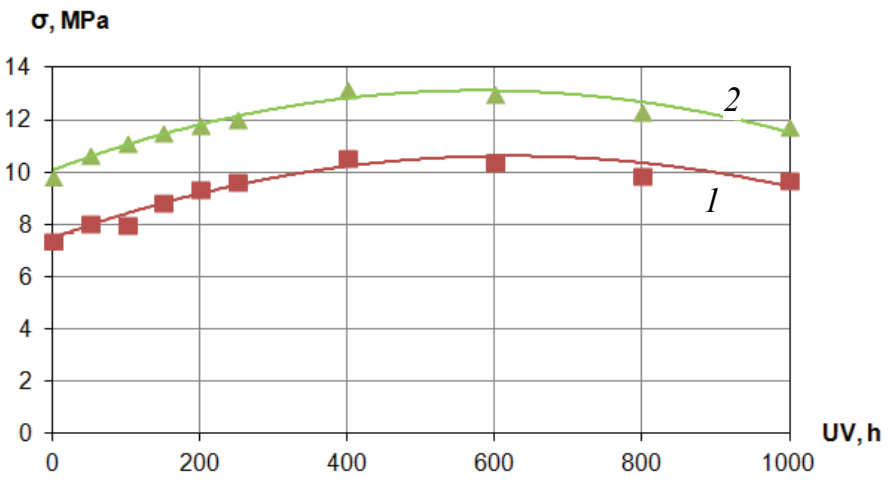

Fig. 3. Correlation between the strength of PVC membranes and UV aging duration: 1 - PLASTFOIL ${ }^{\circledR}$ ECO 1.5; 2 - PLASTFOIL ${ }^{\circledR}$ Classic 1.2

the extension occurred more linearly. In $[12,27,28]$ it was confirmed that when PVC membranes are used as a roofing material, the possibility of thermal extension under the influence of high temperatures and increase in plasticity should be taken into account. The average values of the coefficients of linear thermal extension for the studied samples under are given in Table 1.

Fig. 5 shows the intensity of color change in the upper contrast layer of PVC membrane samples exposed to UV radiation for $0 ; 50 ; 100 ; 150 ; 200 ; 250$ and 1000 hours.

Fig. 5 shows that UV radiation with prolonged exposure enables the fading of the upper layers of PVC membranes. PVC underwent the changes under atmospheric conditions in comparatively thin surface layers [3, 12]. It is stated that the resistance of PVC was largely dependent on the ability of the material to withstand the light influence.

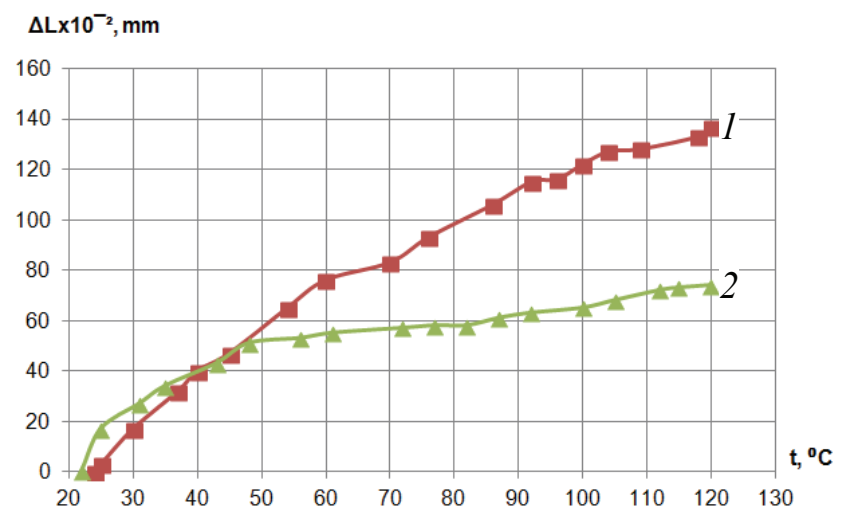

b)

Fig. 4. Dilatometric curves of samples of PVC membranes:

$a$-without external influences; $b$-after 100 hours of UV aging;

1 - PLASTFOIL ${ }^{\circledR}$ ECO 1.5; 2 - PLASTFOIL ${ }^{\circledR}$ Classic 1.2 


\section{Coefficients of linear thermal extension for samples of PVC membranes}

\begin{tabular}{lccc}
\multicolumn{4}{c}{$\begin{array}{c}\text { Coefficients of linear thermal extension } \\
\text { for samples of PVC membranes }\end{array}$} \\
\hline No. & $\begin{array}{c}\text { Type of PVC } \\
\text { membrane }\end{array}$ & $\begin{array}{c}\alpha_{\text {mean }} \cdot 10^{-4}, 1 /{ }^{\circ} \mathrm{C} \\
\text { exthout } \\
\text { influences }\end{array}$ & $\begin{array}{c}100 \text { hours } \\
\text { of UV } \\
\text { aging }\end{array}$ \\
\hline 1 & PLASTFOIL $^{\circledR}$ ECO 1.5 & 2.07 & 2.8 \\
2 & PLASTFOIL $^{\circledR}$ Classic 1.2 & 0.89 & 1.5 \\
\hline
\end{tabular}

Table 1

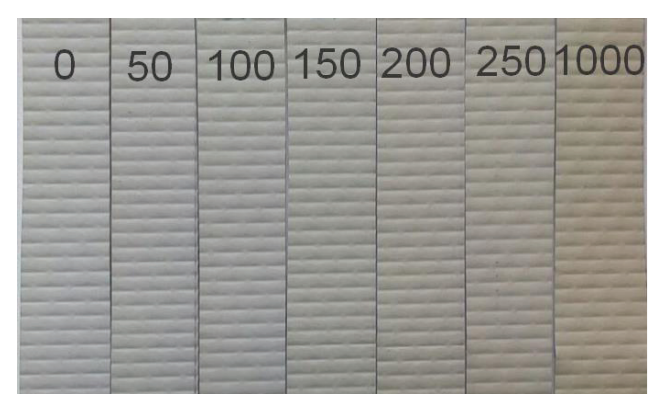

Fig. 5. Color change of samples of PVC membrane PLASTFOIL ${ }^{\circledR}$ Classic 1.2 after exposure to $\mathrm{UV}$ radiation during $0 ; 50 ; 100 ; 150 ; 200 ; 250$ and 1000 hours

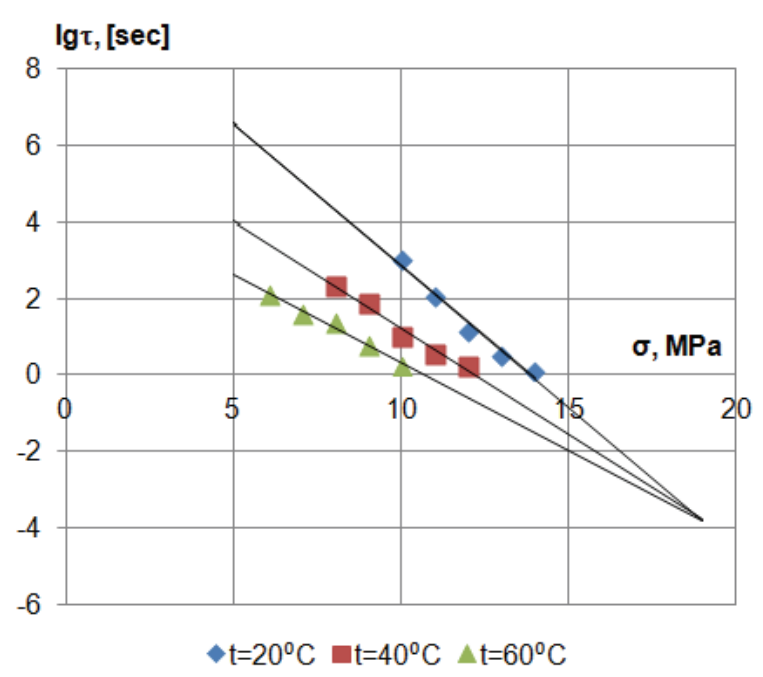

a)

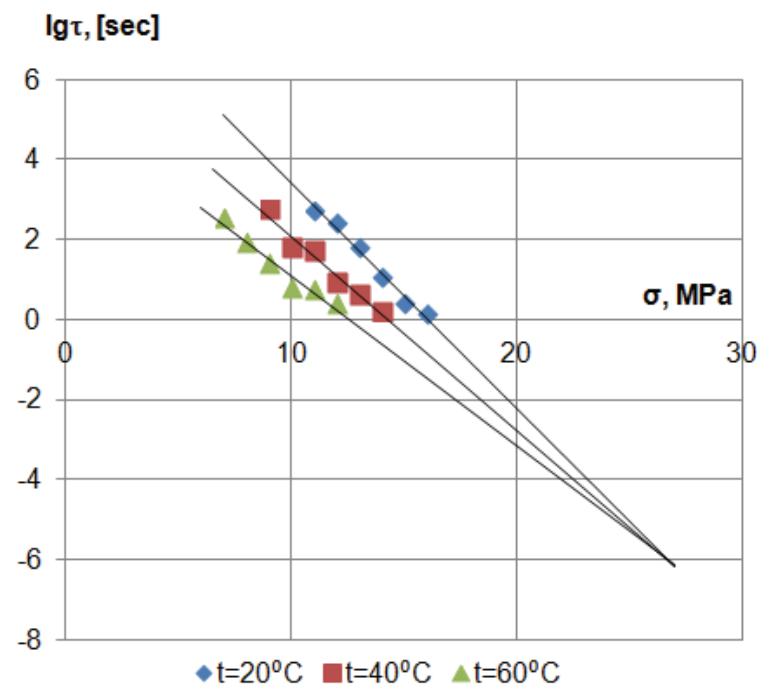

b)

Fig. 6. Dependences of durability from tension at shear of PVC membranes: $a$ - PLASTFOIL ${ }^{\circledR}$ ECO $1.5 ; b$ - PLASTFOIL ${ }^{\circledR}$ Classic 1.2

As a result of long-term tests of PVC membrane samples the dependences of the durability on the shear tension, shown in Fig. 6, were obtained.

Fig. 6 shows that the dependences for the samples represent a family of straight lines forming a "direct beam" and converging at one point - "pole". For these materials the temperature-time dependence of the strength is clearly developed. With increasing temperature, the angle of inclination of the straight line decreases, i.e., the longevity at a given tension value decreases. The obtained values of physical constants for the studied samples of PVC membranes are presented in Table 2.

Table 3 shows the durability of the materials under study at different tension and temperature values.

Table 3 shows that under ideal conditions without the influence of various environmental factors the material can serve for a rather long time. However, under real operating conditions, the durability is significantly affected by temperature changes, humidity, UVI and other factors. Knowing the values of physical constants, according to formula (4) the durability can be calculated, as well as other parameters of PVC membrane operability (strength and heat resistance) at specified voltage, temperature and operating time.

Table 2

Values of physical constants for PVC membranes

\begin{tabular}{lccccc}
\hline No. & $\begin{array}{c}\text { Type of PVC } \\
\text { membrane }\end{array}$ & $T_{m}, \mathrm{~K}$ & $\tau_{m}, \mathrm{~s}$ & $\begin{array}{c}U_{0}, \\
\mathrm{~kJ} / \mathrm{mol}\end{array}$ & $\begin{array}{c}\gamma, \\
\mathrm{kJ} / \mathrm{mol} \cdot \mathrm{MPa}\end{array}$ \\
\hline 1 & PLASTFOIL $^{\circledR}$ ECO 1.5 & 425.5 & $1.55 \cdot 10^{-4}$ & 248.3 & 13.05 \\
2 & PLASTFOIL $^{\circledR}$ Classic 1.2 & 574.7 & $8.13 \cdot 10^{-7}$ & 171.9 & 6.387 \\
\hline
\end{tabular}


Table 3

Values of durability $\tau$ (years) for given values of tension and temperature for PVC membranes

\begin{tabular}{lccccc}
\hline No. & $\begin{array}{c}\text { Type of PVC } \\
\text { membrane }\end{array}$ & $\begin{array}{c}\sigma, \\
\mathrm{MPa}\end{array}$ & 0 & 18 & 50 \\
\hline \multirow{3}{*}{$1 \quad{ }^{\circ} \mathrm{C}$} \\
& \multirow{2}{*}{ PLASTFOIL $^{\circledR}$ ECO 1.5 } & 0.0 & 527 & 42.7 & 3.6 \\
& & 0.5 & 374 & 29.6 & 2.1 \\
& & 2.0 & 123 & 9.3 & 0.7 \\
& & 0.0 & 298 & 32.9 & 2.3 \\
& & 0.5 & 173 & 19.7 & 1.6 \\
& & 2.0 & 89 & 3.5 & 0.5 \\
\hline
\end{tabular}

From the changed values of physical constants, the effect of external atmospheric and climatic influences on the durability of polymer membranes can be estimated.

\section{Conclusion}

1. The test results showed that the durability of PVC membranes can be predicted using the thermofluctuation theory of the strength of solids. Based on the obtained values of physical constants, the durability was calculated, as well as other operating parameters (strength and heat resistance) at specified tension, temperature and operating time.

2. Under ideal conditions the material can serve for a rather long time (more than 100 years). A number of experiments were carried out after the thermal and ultraviolet aging influence on material to obtain more accurate durability values. From the changed values of physical constants, one can consider the effect of external atmospheric and climatic influences on the durability of polymer membranes.

3. When exposed to UV aging, the strength of PVC membranes increased with the rise in duration from 0 to 400 hours on average by $20 \%$. When the duration of UV exposure increased, the strength decreased, which was associated with the beginning of destructive processes. At later stages of aging, the strength decreased monotonically due to accumulation of microdamages.

4. Dilatometric tests showed that the structure of the material and the effect of external factors had a direct effect on the thermal extension of PVC membrane samples. After 100 hours of UV aging the relative extension of the samples increased by an average of $30 \%$ relative to the original values, i.e. the material became more plastic; the structure of all the materials was levelled and the extension occurred more linearly.

\section{References}

1. Zarubina L. P. Gidroizolyatsiya konstruktsiy, zdaniy $i$ sooruzheniy [Waterproofing of structures, buildings and structures]. St. Petersburg: BHV-Petersburg, 2011. 155 p. (Rus)

2. Suvorova Yu.V., Alekseyeva S.I. Eksperimentalnyye $i$ analiticheskiye metody otsenki dolgovechnosti geosinteticheskikh materialov [Experimental and analytical methods for assessing the durability of geosynthetic materials] Problemy mashinostroyeniya i nadezhnosti mashin [Problems of machine building and machine reliability]. 2010, issue 4, pp. 105-110. (Rus)

3. Emanuel N.M., Bugachenko A.L. Khimicheskaya fizika stareniya i stabilizatsii polimerov [Chemical physics of aging and stabilization of polymers]. Moscow: Nauka, 1988. p. 368. (Rus)

4. Hiroyuki Miyauchi, Nobuo Katou, Kyoji Tanaka. Force transfer mechanism on fastener section of mechanically anchored waterproofing membrane roofs under wind pressure during typhoons. Journal of Wind Engineering and Industrial Aerodynamics, vol. 99, issue 11, November 2011, pp. 1174-1183.

5. Hiroyuki Miyauchi, Nobuo Katou, Kyoji Tanaka. Behavior of a mechanically anchored waterproofing membrane system under wind suction and uniform Pressure. Building and Environment, vol. 46, issue 5, May 2011, pp. 1047-1055.

6. Glotov D.A., Kulchayev T.E., Kulchayev A.E., Erkenov R.M., Taushunayev Sh.A. Analiz ukhudsheniya gidroizolyatsionnykh obolochek [Analysis of deterioration of waterproofing shells] Perspektivy nauki [Perspectives of science]. 2017, vol. 3 (90), pp. 70-73. (Rus)

7. Paolini R., Zinzi M., Poli T., Carnielo E., Giovanni Mainini A. Effect of ageing on solar spectral reflectance of roofing membranes: Natural exposure in Rome and Milan and the impact on the energy needs of commercial buildings. Energy and Buildings, vol. 84, December 2014, pp. 333-343.

8. Navratilova Rovenskaa K., Jiranek M., Kacmarikova V. The influence of long-term degradation of waterproof membranes on mechanical properties and on the radon diffusion coefficient. Journal of Cleaner Production, vol. 88, 1 February 2015, pp. 369-375.

9. Pavlov N.N. Stareniye plastmass v yestestvennykh $i$ iskusstvennykh usloviyakh [Aging of plastics in natural and artificial conditions]. M.: Khimiya, 1982. 224 p. (Rus)

10. Suleymanov A.M. Issledovaniye fotostareniya polivinilkhloridnykh materialov. Chast 1. Izmeneniya fiziko-mekhanicheskikh svoystv [Study of photoaging of PVC materials. Part 1. Changes in physical and mechanical properties] Izvestiya KGASU. 2011, issue 2, pp. 241-245. (Rus)

11. Suleymanov A.M. Issledovaniye fotostareniya polivinilkhloridnykh materialov. Chast 2. Strukturnyye izmeneniya [Study of photoaging of PVC materials. Part 2. Structural changes]. Izvestiya KGASU, vol. 2 (16), pp. 246-250. (rus)

12. Ulyanov V.M., Rybkin E.P., Gutkovich A.D., Pishin G.A. Polivinilkhlorid [Polyvinyl chloride]. M.: Khimiya, 1992. 288 p. (Rus)

13. Yartsev V.P., Mamontov A.A., Mamontov S.A. Vliyaniye vneshnikh vozdeystviy na teplofizicheskiye $i$ 
dlitelnyye mekhanicheskiye svoystva mineralovatnykh plit [Influence of external impacts on thermal and physical and long mechanical properties of mineral wool boards.] Voprosy sovremennoy nauki i praktiki. Universitet im. V.I. Vernadsky. [Issues of modern science and practice. University of V.I. Vernadsky]. Tambov, 2014, vol. 1 (50), pp 125-134. (Rus)

14. Friedrich D., Luible A. Investigations on ageing of wood-plastic composites for outdoor applications: A metaanalysis using empiric data derived from diverse weathering trials. Construction and Building Materials. 2016, vol. 124, pp. $1142-1152$.

15. Mamontov S.A., Kiseleva O.A. Teplovoye $i$ svetovoye stareniye fanery stroitelnogo naznacheniya [Thermal and light aging of plywood for construction purposes] Vestnik of Civil Engineers. 2014, vol. 5 (46), pp. 85-89. (Rus)

16. Mamontov S.A., Kiseleva O.A. Issledovaniye teplovogo i svetovogo stareniya drevesnostruzhechnykh plit [Study of heat and light aging of chipboard] Stroitelnyye materialy, oborudovaniye, tekhnologii XXI veka. [Building materials, equipment, technologies of XXI century]. 2015, issue 3, pp.40-43. (Rus)

17. Loginova I.I., Artamonova D.A., Stolyarov O.N., Melnikov B.Ye. Vliyaniye struktury na vyazkouprugiye svoystva geosinteticheskikh materialov [Influence of structure on viscoelastic properties of geosynthetic materials] Magazine of Civil Engineering. 2015, vol. 4(56), pp. 11-18. (Rus)

18. Regel V.R. Kineticheskaya priroda prochnosti tverdykh tel. [Kinetic nature of strength of solids.] Moscow: Nauka, 1974, 560 p. (Rus)

19. Ratner S.B., Yartsev V.P. Fizicheskaya mekhanika plastmass. Kak prognoziruyut rabotosposobnost? [Physical mechanics of plastics. How do they predict capacity?] Moscow: Khimiya, 1992, 320 p. (Rus)

20. Duggal S.K. Building Materials 3rd Edition, New Age International (P) Ltd. New Delhi, 2008, 525 p.

21. Monteiro P.J.M., Chong K.P., Larsen-Basse J., Komvopoulos K. Long Term Durability of Structural Materials 2000. Elsevier Science. Kidlington, 2000. 296 p.

22. Zezin Yu.P. Evaluation of time to fracture for polymeric materials with strong dependence of mechanical properties of mechanical properties on strain rate. 20th European Conference on Fracture. Procedia Materials Science. 2014, issue, 3, pp. 1656-1662.

23. Toshin D.S., Misko Ye.A., Firsova T.G. Planirovaniye eksperimentalnogo issledovaniya po otsenke prochnostnykh $i$ deformativnykh parametrov PVKh membrany [Planning of experimental study of strength and deformation parameters of PVC membrane]. Molodoy uchenyy [Young scientist]. 2016, issue, 20. pp. 210-213. (Rus)

24. Dalinchuk V.S., Ilmenderov M.S., Polenov D.V. Remontoprigodnyye gidroizolyatsionnyye sistemy [Repairable waterproofing systems] Construction of Unique Buildings and Structures. 2015, vol. 7 (34), pp. 71-84.

25. Talib R., Boyd D., Hayhow S., Ahmad A.G., Sulieman M. Investigating effective waterproofing materials in preventing roof leaking; initial comparative study: Malaysia, U.K. 2nd International Materials, Industrial, and Manufacturing Engineering Conference, Procedia Manufacturing. 2015, issue, 2, pp. 419-427.
26. Sakhare V., Raut S., Ralegaonkar R. Performance assessment of sustainable composite roofing assemblies using experimentation. International Conference on Sustainable Design, Engineering and Construction. Procedia Engineering. 2015, issue 118, pp. 268-275.

27. Mohamed H.I., Lee J., Chang J.D. The Effect of Exterior and Interior Roof Thermal Radiation on Buildings Cooling Energy. International Conference on Sustainable Design, Engineering and Construction. Procedia Engineering. 2016, issue 145, pp. 987-994.

28. Cremers J., Palla N., Buck D., Beck A., Biesinger A., Brodkorb S. Analysis of a Translucent Insulated Triple-Layer Membrane Roof for a Sport Centre in Germany. International Symposium on "Novel structural skins - Improving sustainability and efficiency through new structural textile materials and designs". Procedia Engineering. 2016, issue 155 , pp. $38-46$.

29. Joao L.S., Carvalho R., Fangueiro R. A study on the durability properties of textile membranes for architectural purposes. International Symposium on "Novel structural skins - Improving sustainability and efficiency through new structural textile materials and designs". Procedia Engineering. 2016, issue 155, pp. 230-237.

30. Asdrubali F., D'Alessandro F., Schiavoni S. A review of unconventional sustainable building insulation materials. Sustainable Materials and Technologies. 2015, issue 4, pp. 1-17.

31. Zagorodnikova M.A., Yartsev V.P. Prognozirovaniye dolgovechnosti gidroizolyatsionnykh krovelnykh membran na osnove polivinilkhlorida [Prediction of durability of waterproofing roofing membranes based on polyvinyl chloride.] Academia. Arkhitektura i stroitelstvo. [Academia. Architecture and construction.] 2015, issue 3, pp. 139-141.(Rus)

32. Zagorodnikova M.A., Yartsev V.P. Vliyaniye faktorov stareniya na dolgovechnost polivinilkhloridnykh materialov [Influence of aging factors on durability of polyvinylchloride materials.] Nauchnyy vestnik Voronezhskogo gosudarstvennogo arkhitekturno-stroitelnogo universiteta. Seriya: Fiziko-khimicheskiye problemy $i$ vysokiye tekhnologii stroitelnogo materialovedeniya. [Scientific vestnik of Voronezh State Architectural and Construction University. Series: Physicochemical problems and high technologies of building materials science.] 2015, issue 2, pp. 13-18 (Rus)

33. Zagorodnikova M.A., Yartsev V.P. Vliyaniye klimaticheskikh vozdeystviy na termicheskoye rasshireniye listovoy polimernoy krovli [Influence of climatic influences on thermal expansion of sheet polymeric roof.] Molodezh $i$ nauchno-tekhnicheskiy progress: Sbornik dokladov VIII mezhdunarodnoy nauchno-prakticheskoy konferentsii studentov, aspirantov $i$ molodykh uchenykh. [Youth and scientific and technical progress: Collection of reports of VIII international scientifical-practical conference of students, post-graduate students and young scientists] In vol. 4. Vol. 3. Stary Oskol: JSC “Assistant Plus”, 2015, pp. 34-37. (Rus)

34. Ivanov D.V., Yartsev V.P. Povyshenie fiziko-mekhanicheskih harakteristik $i$ dolgovechnosti penopolistirola [Improving the physicomechanical characteristics and durability of polystyrene] .Transactions of Tambov State Technical University. 2011, vol. 2 (17), pp. 529-534. 